\title{
In vitro evaluation of verapamil and other modulating agents in Brazilian chloroquine-resistant Plasmodium falciparum isolates
}

\author{
Avaliação in vitro do verapamil e de outros agentes moduladores em \\ isolados de Plasmodium falciparum resistentes à cloroquina \\ Carla M.S. Menezes ${ }^{1}$, Karin Kirchgatter ${ }^{2}$, Sílvia M. Di Santi ${ }^{2}$, Carine Savalli ${ }^{3}$, \\ Fabíola G. Monteiro ${ }^{3}$, Gilberto A. Paula ${ }^{3}$ and Elizabeth I. Ferreira ${ }^{1}$
}

\begin{abstract}
Verapamil, was assayed to record its modulating effect upon Brazilian Plasmodium falciparum isolates resistant to chloroquine. Other cardiovascular drugs known to be modulating agents in resistant malaria and/or multidrug-resistant neoplasias, including nifedipine, nitrendipine, diltiazem and propranolol, were also evaluated. Concentrations similar to those for cardiovascular therapy were used in the in vitro microtechnique for antimalarial drug susceptibility. Intrinsic antiplasmodial activity was observed from the lowest concentrations without a significant modulating action. Other reported modulating agents, such as the antipsychotic drug trifluoperazine and the antidepressants desipramine and imipramine, demonstrated similar responses under the same experimental conditions. Results suggest a much higher susceptibility of Brazilian strains, as well as an indifferent behaviour in relation to modulating agents.
\end{abstract}

Key-words: Chloroquine. Multidrug-resistance. Verapamil. Modulating agents. Reversal agents.

Resumo Verapamil foi ensaiado quanto ao efeito modulador em isolados brasileiros de Plasmodium falciparum resistentes à cloroquina. Outros agentes cardiovasculares, considerados como moduladores da resistência em malária e/ou em neoplasias multiresistentes a fármacos, como nifedipino, nitrendipino, diltiazem e propranolol foram ensaiados quanto ao mesmo efeito. Concentraçốes semelhantes às da terapia cardiovascular foram empregadas no ensaio de microtécnica de sensibilidade para fármacos antimaláricos. Atividade antiplasmódica intrínsica foi observada desde as menores concentrações, sem, entretanto, ocorrência de modulação significativa da resistência. Sob as mesmas condições experimentais, respostas semelhantes foram observadas para outros agentes moduladores conhecidos como o antipsicótico trifluoperazina e os antidepressivos desipramina e imipramina. Em conjunto, estes resultados sugerem alta sensibilidade e comportamento indiferente de cepas brasileiras ao efeito de agentes moduladores da resistência.

Palavras-chaves: Cloroquina. Resistência múltipla a fármacos. Verapamil. Agentes moduladores da resistência. Agentes reversores da resistência.

Malaria is a parasitic disease that has affected man since primeval times. Nowadays, it is considered to be the most pernicious infectious disease transmissible by mosquitoes. Millions of people are infected in tropical and sub-tropical areas and over one million deaths per year are estimated to occur. Insecticide and drug resistance are major problems for the control of the disease, particularly the resistance of most Plasmodium falciparum strains to chloroquine ${ }^{11}$.
In 1987, Martin et a/15 suggested that multidrug resistance (MDR) may be a possible mechanism to explain the resistance of $P$. falciparum to chloroquine, since the combination of verapamil with chloroquine caused reversal of in vitro antimalarial resistance.

With the object of evaluating the in vitro modulation of chloroquine resistance in fresh Brazilian isolates of $P$. falciparum, a series of compounds were assayed reportedly to be modulating agents in resistant malaria

\footnotetext{
1. Faculdade de Ciências Farmacêuticas da Universidade de São Paulo, São Paulo, SP. 2. Superintendência de Controle de Endemias (SUCEN), São Paulo, SP. 3. Instituto de Matemática e Estatística da Universidade de São Paulo, São Paulo, SP, Brazil.

Financial Support: CNPq

Address to: Dra. Elizabeth Igne Ferreira. Dept ${ }^{\circ}$ de Farmácia/FCF/USP. Av. Prof. Lineu Prestes 580, Cidade Universitária, Caixa Postal 660823, 05389-970 São Paulo, SP, Brazil.

Fax $5511815-4418$

e-mail:hajudan@usp.br

Recebido para publicação em 20/7/2001.
} 
and/or multidrug-resistant neoplasias. This paper reports the results observed for the cardiovascular drugs verapamil ( $R, S$-verapamil), nifedipine, nitrendipine, diltiazem and propranolol. In addition, the results observed for other modulating agents, such as the phenothiazine antipsychotic drug trifluoperazine ${ }^{19}$ and the tricyclic antidepressants desipramine and imipramine ${ }^{17}$, were also recorded to characterize the behavior of Brazilian strains. The chemical structures of all studied drugs, including the antidepressant agents imipramine and desipramine and the antipsychotic trifluoperazine are depicted in Figure 1.<smiles>CCN(CC)CCCC(C)Nc1ccnc2cc(Cl)ccc12</smiles><smiles>[R9][R9](=O)[C@H](C)C(C)(C)C(C#N)(CCCN(C)CCc1ccc(OC)c(OC)c1)c1ccc(OC)c(OC)c1</smiles><smiles>CN1CCN(CCCN2c3ccccc3Sc3ccc(C(F)(F)F)cc32)CC1</smiles>

trifluoperazine<smiles>[R1]N(C)CCCN1c2ccccc2CCc2ccccc21</smiles>

R1

imipramine $\mathrm{CH}_{3}$ desipramine $\mathrm{H}$<smiles>CCc1nc(C)c(C)c(CC)c1C(=O)OC</smiles><smiles>CC(=O)OC1C(=O)N(CCN(C)C)c2ccccc2SC1c1ccccc1</smiles><smiles>CC(C)NCC(O)COc1cccc2ccccc12</smiles>

Figure 1 - Chemical structures of chloroquine, and of cardiovascular, antidepressant and antipsychotic drugs studied as modulating agents in Brazilian chloroquine-resistant $\mathrm{P}$. falciparum isolates. 


\section{MATERIAL AND METHODS}

Drugs employed were $R, S$-verapamil hydrochloride (Knoll S/A Produtos Químicos e Farmacêuticos, Brazil), nifedipine and nitrendipine (Laboratórios Biosintética Ltda, Brazil), diltiazem hydrochloride (Boehringer De Angeli Química e Farmacêutica Ltda, Brazil) and propranolol hydrochloride. The two chloroquine-resistant strains were obtained from patients who had been infected in the northern region of Brazil. Isolate 1 (SUCEN 198/94) was collected from a 37-year-old woman in her third infection (6,600 asexual parasites per $\mathrm{mm}^{3}$ ). Isolate 2 (SUCEN 206/94) was from a 21 yearold-man in his second infection (7,500 asexual parasites per $\left.\mathrm{mm}^{3}\right)$. The patients had not received any antimalarial treatment during the previous 28 days $\mathbf{s}^{6}$. Blood samples were collected after formal consent from the patients. The biological assay was performed on microplates with 96 flat-bottomed wells and the culture medium used was RPMI-1640 supplemented with HEPES buffer, gentamicin sulfate, glucose, hypoxanthine, sodium bicarbonate, and human type A serum. The S-Plus software, version 4.5, and Microsoft Excel for Windows, version 5.0, were used for statistical analysis.

Biological assay. The modulating effect was evaluated by the in vitro microtechnique for antimalarial drug susceptibility ${ }^{24}$. Microplates were titrated with twofold serial dilutions so that the intermediate value corresponded to the current cardiovascular therapeutic concentration $^{3}{ }^{7}$. Verapamil has intermediate concentrations of $125 \mu \mathrm{g} / \mathrm{L}$. Similarly, nifedipine and nitrendipine were assayed at $40 \mu \mathrm{g} / \mathrm{L}$, and diltiazem and propranolol at 50 $\mathrm{gg} / \mathrm{L}$. Two plates were prepared and chloroquine was added to one at a fixed concentration of $30 \mu \mathrm{g} / \mathrm{L}^{3}$. Chloroquine antimalarial activity was assayed in the range of 3.75 to $240 \mu \mathrm{g} / \mathrm{L}$. A $10 \%$ hematocrit solution of infected blood was added to the plates, which were incubated according to the candle jar method ${ }^{26}$ at $37^{\circ} \mathrm{C}$ for 46 (Isolate 1) and 48 (Isolate 2) hours. Schizonts with three or more nuclei in 200 parasites were counted.

Statistical analysis. A descriptive study was performed to analyze the parasitaemia rate as a function of drug concentration. The parasitaemia rate corresponded to the number of parasites in each drug concentration in relation to that in the respective control. Two lines were constructed, one for the modulating agent and the other for the combination with chloroquine. Coincident and separate (parallel and concurrent with one or two intercepts) lines were further fitted using the logistic and log-log complement models in the inferential analysis ${ }^{5}{ }^{8}$. A $10 \%$ significance level was adopted for the likelihood ratio statistic, which, in this case, corresponded to the difference between two goodnessof-fit statistics.

\section{RESULTS}

With both isolates and with the different cardiovascular drugs, a decrease in parasitaemia rate as a consequence of increasing drug concentration was observed whether or not the drug was combined with chloroquine. A similar decrease was observed with chloroquine (Figure 2). Using inferential analysis, a coincident lines model fitted the best for the lines of verapamil and its combination with chloroquine. Coincident lines were the most suitable fitted model for the other cardiovascular compounds assayed, with the exception of nitrendipine for which parallel lines was the best fit for Isolate 1 (data not shown). In order to illustrate these findings, Figure 2 and Table 1 show the verapamil results against Isolate 1 . Similar results were obtained for Isolate 2.

\section{DISCUSSION}

Verapamil may be considered to be the first modulating agent in multidrug-resistant neoplasias ${ }^{28}$. Martin et a/15 observed that this drug reversed in vitro $P$. falciparum resistance to chloroquine and the MDR mechanism has been uggested to malaria. Furthermore, other cardiovascular agents such as diltiazem $^{131426}$, nicardipine ${ }^{26}$, amlodipine ${ }^{2}$ and different therapeutic drugs such as desipramine ${ }^{4}$, cyproheptadine ${ }^{23}$ and promethazine ${ }^{20}$, were shown to modulate antimalarial drug resistance. From these, the anti-histaminic chlorpheniramine has been successfully employed in combination with chloroquine to treat Nigerian children with falciparum malaria ${ }^{21}$.

In our work, a particular procedure was adopted with the aim of simulating the modulating effect of drugs at therapeutic schedules. The current therapeutic concentration was employed as the intermediate concentration in the two-fold serial dilutions of the modulating agents (ca. $125 \mu \mathrm{g} / \mathrm{L}$ for verapamil) and a fixed concentration of chloroquine $(30 \mu \mathrm{g} / \mathrm{L})$ was combined. This chloroquine concentration is responsible for the clearance of parasitaemia in sensitive $P$. falciparum infections ${ }^{3}$. Thus, if a modulating effect was observed, chloroquine was considered to be therapeutically efficient. An analogous drug combination was used to determine the response modification index (RMI), with the exception that the modulating effect was evaluated with respect to the median inhibitory concentration $\left(\mathrm{IC}_{50}\right)$ of the antimalarial agent ${ }^{1420}$.

In this study, the descriptive statistical analysis showed a decrease in the parasitaemia rate as a function of concentration for all the compounds and combinations assayed (Figure 2). Chloroquine sensitivity was observed at the highest concentrations classifying the strains as resistant to the antimalarial ${ }^{6} . I C_{50}$ values and the $95 \%$ confidence interval (in parentheses) were 
A

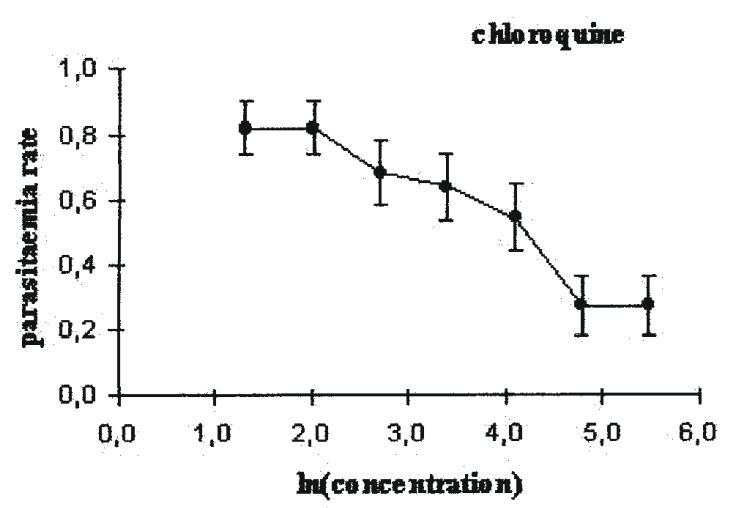

$\mathbf{B}$

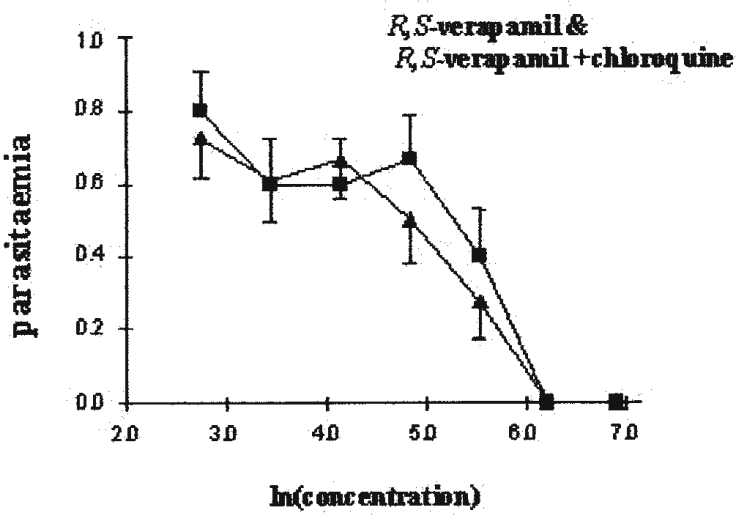

Figure 2 - Ratios of the number of $\mathrm{P}$. falciparum parasites in drug-treated cultures to the number in control cultures (parasitaemia rate) after $46 \mathrm{~h}$ exposure to chloroquine $(A)$ and to verapamil $(R, S-v e r a p a m i l)(\Delta)$ and verapamil plus chloroquine (₫) (B) for Isolate 1.

Table 1 - Fitted linear logistic model for verapamil (R,S-verapamil).

\begin{tabular}{|c|c|c|c|c|c|}
\hline Lines models & Goodness-of-fit statistic & Degrees of freedom & $\begin{array}{l}\text { Likelihood ratio } \\
\text { statistic }\end{array}$ & $\begin{array}{c}\text { Differences in degrees } \\
\text { of freedom }\end{array}$ & $P$ \\
\hline Coincident & 26.775 & 12 & - & - & - \\
\hline Parallels & 26.195 & 11 & 0.579 & 1 & 0.446 \\
\hline Concurrent (1 intercept) & 26.177 & 11 & 0.598 & 1 & 0.439 \\
\hline Concurrent (2 intercepts) & 26.174 & 10 & 0.601 & 2 & 0.741 \\
\hline
\end{tabular}

$52.46 \mu \mathrm{g} / \mathrm{L}(30.57$ - 74.41) for Isolate 1 and $41.26 \mu \mathrm{g} / \mathrm{L}$ (22.87 - 74.40) for Isolate 2.

However, it is important to note that under the adopted experimental conditions, the intrinsic antiparasitic activity observed for modulating agents was not expected. For example, $1 \mu \mathrm{M}$ verapamil was considered ineffective against parasite growth in antimalarial resistance reversal studies ${ }^{15}$, this effect being only reported at $10 \mu \mathrm{M}^{1}$. In this study, verapamil was evaluated at serial dilutions ranging from 15.63 to $1,000.00 \mu \mathrm{g} / \mathrm{L}(0.034-2.2 \mu \mathrm{M})$ and showed antimalarial activity from the initial concentration. Similar considerations can be established in respect to the other compounds. Moreover, the fitting of coincident lines is indicative of a non-significant change in parasitaemia rate when chloroquine was combined. Nitrendipine demonstrated contrasting results to those of the other cardiovascular drugs, and in the total series studied with erythromycin ${ }^{18}$, which showed a weak modulating effect only for Isolate 1.

In general, intrinsic antiplasmodial activity and lack of chloroquine resistance modulation were observed for most of the modulating agents assayed, such as the antipsychotic drug trifluoperazine ${ }^{19}$ and the antidepressants desipramine and imipramine ${ }^{17}$.

Independently of the mechanism of action responsible for the intrinsic antiplasmodial effect ${ }^{9} 1012$ 2124 , our final results (as far as we know, this is the first study performed with fresh isolates), suggest a much higher susceptibility of Brazilian strains, as well as an indifferent behaviour, in response to modulating agents as reported by Mehlotra ${ }^{16}$. They associated this finding to genetic polymorphis among chloroquine-resistant strains from different endemic areas.

\section{REFERENCES}

1. Adovelande J, Délèze J, Schrével J. Synergy between two calcium channel blockers, verapamil and fantofarone (SR33557), in reversing chloroquine resistance in Plasmodium falciparum. Biochemical Pharmacology 55: 433-440, 1998.

2. Basco LK, Le Bras J. Plasmodium falciparum: in vitro drug interaction between chloroquine and enantiomers of amlodipine. Experimental Parasitology 72: 262-270, 1991.

3. Benet LZ, le S, Schwartz JB. Design and Optimization of Dosage Regimens: Pharmacokinetic Data. In: Hardman JG, Limbird LE, Molinoff PB, Ruddon RW, Gilman AG (eds) Goodman \& Gilman's:
The Pharmacological Basis of Therapeutics, $9^{\text {th }}$ edition, Pergamon Press, New York, p. 1707-1792, 1996.

4. Bitonti AJ, Sjoerdsma A, McCann PP, Kyle DE, Oduola AMJ, Rossan RN, Milhous WK, Davidson Jr DE. Reversal of chloroquine resistance in malaria parasite Plasmodium falciparum by desipramine. Science 242: 1301-1303, 1988.

5. Breslow NE, Day NE. Statistical Methods in Cancer Research 1. The Analysis of Case Control Studies. International Agency for Research on Cancer, Lyon, 1980. 
6. Bruce-Chwatt LJ (ed) Chemotherapy of Malaria, $2^{\text {nd }}$ edition, World Health Organization, Geneva, p. 211-233, 1982.

7. Clarke EC. Isolation and Identification of Drugs in Pharmaceuticals, Body Fluids and Post-mortem Material, $2^{\text {nd }}$ edition, Pharmaceutical Press, London, 1986.

8. Collett D. Modelling Binary Data. Chapman \& Hall, London, 1991.

9. Domínguez JN, López S, Charris J, larruso L, Lobo G, Semenov A, Olson JE, Rosenthlal PJ. Synthesis and antimalarial effects of phenothiazine inhibitors of a Plasmodium falciparum cysteine protease. Journal of Medicinal Chemistry 40: 2726-2732, 1997.

10. Honegger UE, Roscher AA, Wiesmann UN. Evidence for lysosomotropic action of desipramine in cultured human fibroblasts. Journal of Pharmacology and Experimental Therapeutics 225: 436-441, 1983.

11. Introducing MMV. The medicines for malaria venture. Fact Sheets. Background Document. [www.who.int/inf-fs/en/factXXX.html in 0330-01]. World Health Organization Information, November 1999.

12. Kanno K, Sasaki Y. Interaction of psychotropic drugs with phospholipids. Biochemical Pharmacology 31: 2977-2981, 1982.

13. Krogstad DJ, Gluzman IY, Kyle DE, Oduola AMJ, Martin SK, Milhous WK, Schlesinger PH. Efflux of chloroquine from Plasmodium falciparum: mechanism of chloroquine resistance. Science 238: 1283-1285, 1987.

14. Kyle DE, Oduola AMJ, Martin SK, Milhous WK. Plasmodium falciparum: modulation by calcium antagonists of resistance to chloroquine, desethylchloroquine, quinine, and quinidine in vitro. Transactions of the Royal Society of Tropical Medicine and Hygiene 84: 474-478, 1990.

15. Martin SK, Oduola AMJ, Milhous WK. Reversal of chloroquine resistance in Plasmodium falciparum by verapamil. Science 235 : 899-901, 1987.

16. Mehlotra RK, Fujioka H, Roepe PD, Janneh O, Ursos LM, JaobsLorena V, McNamara DT, Bockarie MJ, Kazura JV, Kyle DE, Fidock DA, Zimmerman PA. Evolution of a unique Plasmodium falciparum chloroquine-resistance phenotype in association with pfcrt polymorphism in Papua New Guinea and South America. Proceedings of National Academy of Science USA 98: 12689-12694, 2001.

17. Menezes CMS, Kirchgatter K, Di Santi SMF, Savalli C, Monteiro FG, Paula GA, Ferreira El. Antimalarial effect in vitro and lack of modulating effect of desipramine and imipramine. Transactions of the Royal Society of Tropical Medicine and Hygiene 91: 697$700,1997$.
18. Menezes CMS, Kirchgatter K, Di Santi SMF, Savalli C, Monteiro FG, Paula GA, Ferreira El. In vitro evaluation of erythromycin in chloroquine resistant Brazilian P. falciparum freshly isolates: modulating effect and antimalarial evidence. Revista do Instituto de Medicina Tropical de São Paulo 41:249-253, 1999.

19. Menezes CMS, Kirchgatter R, Di Santi SMF, Savalli C, Monteiro FG, Paula GA, Ferreira El. In vitro chloroquine resistance modulation study on fresh isolates of Brazilian Plasmodium falciparum: intrinsic antimalarial activity of phenothiazin drugs. Memórias do Instituto Oswaldo Cruz 97: 1033-1039, 2002.

20. Oduola AMJ, Sowunmi A, Milhous WK, Brewer TG, Kyle DE, Gerena L, Rossan RN, Salako LA, Schuster BG. In vitro and in vivo reversal of chloroquine resistance in Plasmodium falciparum with promethazine. American Journal of Tropical Medicine and Hygiene 58: 625-629, 1998.

21. Okonkwo CA, Coker HAB, Agomo PU, Ogunbanwo JA, Mafe AG, Agomo CO, Afolabi BM. Effect of chlorpheniramine on the pharmacokinetics of and response to chloroquine of Nigerian children with falciparum malaria. Transactions of the Royal Society of Tropical Medicine and Hygiene 93: 306-311, 1999.

22. Panijpan B, Kantakanit N. Chlorpromazine enhances haemolysis induced by haemin. Journal of Pharmacy and Pharmacology 35 : 473-475, 1983.

23. Peters W, Ekong R, Robinson BL, Warhurst DC, Xing-Qing P. The chemotherapy of rodent malaria. XLV. Reversal of chloroquine resistance in rodent and human Plasmodium by antihistaminic agents. Annals of Tropical Medicine and Parasitology 84: 541-551, 1990.

24. Rieckmann KH, Sax LJ, Campbell GH, Mrema JE. Drug sensitivity of Plasmodium falciparum. An in vitro microtechnique. Lancet 1: 22-23, 1978.

25. Scheibel LW, Colombani PM, Hess AD, Aikawa M, Atkinson CT, Milhous WK. Calcium and calmodulin antagonists inhibit human malaria parasites (Plasmodium falciparum): implications for drug design. Proceedings of the National Academy of Science USA 84: 7310-7314, 1987.

26. Tanabe K, Kato M, Izumo A, Hagiwara A, Doi S. Plasmodium chabaudi: in vivo effects of $\mathrm{Ca}^{2+}$ antagonists in chloroquineresistant and chloroquine-sensitive parasites. Experimental Parasitology 70: 419-426, 1990.

27. Trager W, Jensen BB. Human malaria parasites in continuous culture. Science 193: 673-675, 1976.

28. Tsuruo T, lida H, Tsukagoshi S, Sakurai Y. Overcoming of vincristine resistance in P388 leukemia in vivo and in vitro through enhanced cytotoxicity of vincristine by verapamil. Cancer Research 41: 1967-1973, 1981. 